\title{
PENGARUH KECERDASAN EMOSIONAL TERHADAP TINGKAT PEMAHAMAN AKUNTANSI DENGAN KEPERCAYAAN DIRI SEBAGAI VARIABEL PEMODERASI PADA SISWA KELAS XII JURUSAN AKUNTANSI SMKN 1 SUMENEP
}

\author{
Dina Febriastuti \\ MAN 1 Sumenep \\ Dinafebriastuti@yahoo.com
}

\begin{abstract}
This study aims to analyze the direct effect of emotional intellegence towards accounting understanding level and also analyze the indirect effect using self confidence as moderating variable. The sample of this study are 70 accounting students in class XII of SMKN I Sumenep. The research design applied in this study is correlational descriptive using quantitative approach. There are three variables used in this study namely emotional intellegence (X), level of accounting understanding $(\mathrm{Y})$ and self confidence $(\mathrm{Z})$. The analysis used in testing the hypothesis is path anaysis and the result of this study suggests that there is a significant direct effect between emotional intellegence and the level of accounting understanding.
\end{abstract}

Keywords: emotional intelegence, accounting understanding level, self confidence

Abstrak: Penelitian ini bertujuan untuk mengetahui pengaruh langsung kecerdasan emosional terhadap tingkat pemahaman akuntansi dan pengaruh tidak langsung dengan menggunakan variabel kepercayaan diri sebagai pemoderasi. Sampel dalam penelitian ini adalah 70 siswa kelas XII jurusan akuntansi SMKN 1 Sumenep. Rancangan penelitian yang digunakan adalah deskriptif korelasional dengan pendekatan kuantitatif. Variabel penelitian ini adalah kecerdasan emosional (X), pemahaman akuntansi (Y), dan kepercayaan diri (Z). Analisis data yang digunakan untuk menguji hipotesis adalah analisis jalur (path analysis). Berdasarkan analisis data diperoleh kesimpulan bahwa ada pengaruh langsung yang signifikan antara kecerdasan emosional terhadap pemahaman akuntansi sedangkan pengaruh tidak langsung antara kecerdasan emosional dan pemahaman akuntansi melalui variabel kepercayaan diri sebagai variabel pemoderasi.

Kata Kunci: kecerdasan emosional, tingkat pemahaman akuntansi dan kepercayaan diri.

Beberapa fenomena di masyarakat menunjukkan bahwa orang yang mempunyai kecerdasan otak dan gelar yang tinggi belum tentu sukses dalam berkiprah di dunia pekerjaan. Bahkan seringkali yang berpendidikan formal rendah justru bisa lebih berhasil. Hal tersebut dikarenakan kebanyakan program pendidikan dibangku sekolah atau dibangku kuliah umumnya lebih berpusat pada kecerdasan akal (IQ) saja, padahal yang diperlukan sebenarnya adalah 
bagaimana mengembangkan kecerdasan hati, seperti ketangguhan, inisiatif, optimisme serta kemampuan beradaptasi yang kini telah menjadi dasar penilaian baru.

Sebuah laporan dari National Center for Clinical Infant Programs (1992) menyatakan bahwa keberhasilan di sekolah bukan diramalkan oleh kumpulan fakta seorang siswa atau kemampuan dininya untuk membaca, melainkan oleh ukuran-ukuran emosional dan sosial: yakni mempunyai minat, mengetahui pola perilaku yang diharapkan orang lain dan bagaimana mengendalikan dorongan hati untuk berbuat menyimpang, mampu menunggu, mengikuti petunjuk dari guru, serta mengungkapkan kebutuhan-kebutuhan saat bergaul dengan siswa lain. Hampir semua siswa yang prestasi sekolahnya buruk, menurut laporan tersebut, tidak memiliki satu atau lebih unsur-unsur kecerdasan emosional ini (tanpa memperdulikan apakah mereka juga mempunyai kesulitan-kesulitan kognitif seperti ketidakmampuan belajar) (Goleman, 2002:273).

Penelitian Mischel (1960) dalam Goleman (2005) mengenai "marsmallow challenge" di Universitas Stanford menunjukkan anak yang ketika berumur empat tahun mampu menunda dorongan hatinya dan setelah lulus sekolah menengah atas, secara akademis lebih kompeten, lebih mampu menyusun gagasan secara nalar, serta memiliki gairah belajar yang lebih tinggi. Mereka memiliki skor yang secara signifikan lebih tinggi pada tes SAT dibanding dengan anak yang tidak mampu menunda dorongan hatinya.

Lebih lanjut, Goleman juga menyatakan bahwa khusus pada orang-orang murni hanya memiliki kecerdasan akademis tinggi, mereka cenderung memiliki rasa gelisah yang tidak beralasan, terlalu kritis, rewel, cenderung menarik diri, terkesan dingin dan cenderung sulit mengekspresikan kekesalan dan kemarahannya secara tepat. Bila didukung dengan rendahnya taraf kecerdasan emosionalnya, maka orang-orang seperti ini sering menjadi sumber masalah. Seseorang yang memiliki IQ tinggi namun taraf kecerdasan emosionalnya rendah maka cenderung akan terlihat sebagai orang yang keras kepala, sulit bergaul, mudah frustrasi, tidak mudah percaya kepada orang lain, tidak peka dengan kondisi lingkungan dan cenderung putus asa bila mengalami tekanan. Kondisi sebaliknya dialami oleh orang-orang yang memiliki taraf IQ rata-rata namun memiliki kecerdasan emosional yang tinggi.

Individu yang memiliki tingkat kecerdasan emosional yang lebih baik, dapat menjadi lebih terampil dalam menenangkan dirinya dengan cepat, lebih terampil dalam memusatkan 
perhatian, lebih baik dalam berhubungan dengan orang lain, lebih cakap dalam memahami orang lain dan untuk kerja akademis di sekolah lebih baik (Gottman, 2001).

Salah satu profesor pendidikan di Boston University, dan merupakan salah satu diantara para peneliti yang melacak juara-juara pertama dunia, menjelaskan bahwa individu-individu yang rajin bekerja merupakan individu yang mengerti bagaimana menghasilkan prestasi. Untuk menghasilkan sebuah prestasi, pada umumnya individu berjuang sama kuatnya dengan individu yang lain. Selain itu, diketahui pula bahwa prestasi ataupun predikat juara yang dimiliki individu tidak dapat memberi gambaran apapun tentang hal-hal yang dilakukan individu dalam menghadapi kesulitan-kesulitan hidup (Cooper, 2002: 17).

Proses belajar mengajar dalam berbagai aspeknya sangat berkaitan dengan kecerdasan emosional siswa. Kecerdasan emosional ini mampu melatih kemampuan siswa tersebut, yaitu kemampuan untuk mengelola perasaannya, kemampuan untuk memotivasi dirinya, kesanggupan untuk tegar dalam menghadapi frustasi, kesanggupan untuk mengendalikan dorongan dan menunda kepuasan sesaat, mengatur suasana hati yang reaktif, serta mampu berempati dan bekerja sama dengan orang lain. Kemampuan-kemampuan ini mendukung seorang siswa dalam mencapai tujuan dan cita-citanya.

Kecerdasan emosional (EQ) dan kecerdasan intelektual (IQ) saling melengkapi. IQ tanpa EQ dapat membuat seseorang berhasil meraih nilai bagus dalam ujian, namun tidak akan membuat seseorang berhasil dalam kehidupan hubungan pribadi dan antar pribadi. EQ bertanggung jawab atas harga diri, kesadaran diri, kepekaan sosial, dan kemampuan adaptasi sosial individu. Bila EQ seseorang tinggi, maka seseorang tersebut mampu memahami berbagai perasaan secara mendalam ketika perasaan-perasaan yang ditimbulkan oleh EQ muncul, dan dapat mengenali diri sendiri. Menurut Goleman (2002:512), kecerdasan emosional adalah kemampuan seseorang mengatur kehidupan emosinya dengan intelegensi (to manage our emotional life with intelligence); menjaga keselarasan emosi dan pengungkapannya (the oppropriateness of emotion and its expression) melalui keterampilan kesadaran diri, pengendalian diri, motivasi diri, empati dan keterampilan sosial.

Percaya diri (self confidence) adalah meyakini pada kemampuan dan penilainan (judgement) diri sendiri dalam melakukan tugas dan memilih pendekatan yang efektif. Hal ini termasuk kepercayaan atas kemampuannya menghadapi lingkungan yang semakin menantang dan kepercayaan atas keputusan atau pendapatnya. Siswa yang mempunyai kecerdasan 
emosional tinggi dan kepercayaan diri tinggi akan lebih santai dan terarah dalam menyampaikan atau mengemukakan pendapatnya. Karena dengan kecerdasan emosional tinggi siswa akan lebih mampu dalam mengelola dan menahan emosinya. Berdasarkan landasan teori yang telah dikemukakan di atas maka pengembangan hipotesis penelitian ini dapat dirumuskan sebagai berikut:

$\mathrm{H}_{1}$ : Terdapat pengaruh kecerdasan emosional terhadap pemahaman akuntansi.

$\mathrm{H}_{2}$ : Terdapat pengaruh kecerdasan emosional terhadap kepercayaan diri.

$\mathrm{H}_{3}$ : Terdapat pengaruh kepercayaan diri terhadap pemahaman akuntansi.

\section{METODE}

Penelitian ini dilaksanakan dengan menggunakan rancangan penelitian deskriptif korelasional. Penelitian deskriptif merupakan suatu penelitian yang dimaksudkan untuk mengumpulkan informasi mengenai status suatu gejala yang ada menurut apa adanya pada saat penelitian dilakukan. Sedangkan tergolong jenis korelasional karena penelitian ini menerangkan sejauh mana dua variabel atau lebih berkorelasi (berhubungan) dalam hal ini adalah variabel bebas $(\mathrm{X})$, variabel terikat $(\mathrm{Y})$, dan variabel intervening $(\mathrm{Z})$. Variabel bebas $(\mathrm{X})$ yaitu kecerdasan emosional, variabel intervening $(\mathrm{Z})$ yaitu kepercayaan diri, dan variabel terikat ( $\mathrm{Y}$ ) yaitu tingkat pemahaman akuntansi siswa kelas XII jurusan akuntansi SMK Negeri 1 Sumenep.

Variabel dependen dalam penelitian ini adalah tingkat pemahaman akuntansi yang diproksikan dengan rata-rata nilai mata pelajaran yang berkaitan dengan akuntansi, yaitu mata pelajaran siklus akuntansi, akuntansi perbankan, akuntansi biaya, analisis laporan keuangan, akuntansi keuangan, akuntansi perpajakan, dan komputer akuntansi. Sedangkan variabel independen pada penelitian ini adalah kecerdasan emosional yang dikembangkan menjadi lima komponen yaitu pengenalan diri, pengendalian diri, motivasi, empati dan keterampilan sosial.

Untuk mengetahui pengaruh dari variabel $\mathrm{X}$, variabel $\mathrm{Y}$, dan variabel $\mathrm{Z}$ dapat dilihat dari rancangan penelitian sebagai berikut: 


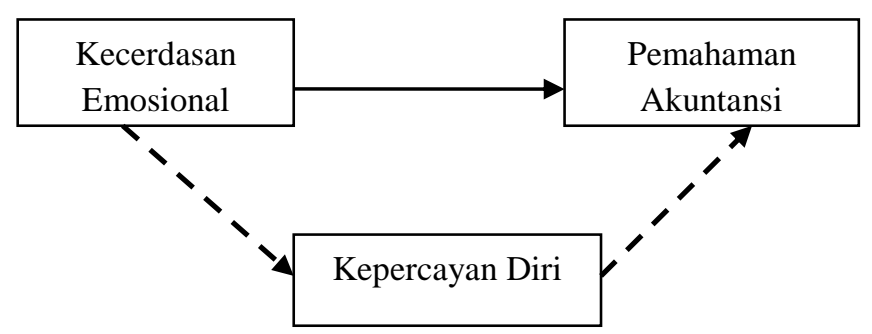

\title{
Gambar 1: Rancangan Penelitian Path Analisis
}

\author{
Keterangan : $\longrightarrow$ hubungan langsung \\ $-\rightarrow$ Hubungan tidak langsung
}

Teknik analisis yang digunakan dalam penelitian ini adalah analisisjalur (path analysis). Model path analysis digunakan untuk menganalisis pola hubungan antar variabel dengan tujuan untuk mengetahui pengaruh langsung maupun tidak langsung seperangkat variabel bebas terhadap variabel terikat (Arikunto, 2006: 22). Jadi teknik ini digunakan untuk menguji hipotesis yang menyatakan ada pengaruh antara variabel bebas dan variabel intervening, pengaruh antara variabel bebas terhadap variabel terikat, serta pengaruh tidak langsung dari variabel bebas terhadap variabel terikat melalui variabel moderator. Kemudahan dalam perhitungan digunakan software SPSS for windows versi 16.0.

Adapun responden penelitian ini adalah siswa SMK kelas tiga jurusan akuntansi yang telah menempuh mata pelajaran siklus akuntansi, akuntansi perbankan, akuntansi biaya, analisis laporan keuangan, akuntansi keuangan, akuntansi perpajakan, hitung dagang, komputer akuntansi yang berjumlah 70 siswa. Alasan menggunakan siswa kelas tiga, karena siswa tersebut telah mendapat manfaat maksimal dari pelajaran akuntansi, siswa kelas tiga mempunyai emosi yang tidak stabil dan pada usia seumuran meraka masih dalam proses pencarian jati diri, begitu juga dengan tingkat kepercayaan diri yang dimilikinya. Jadi penelitian ini termasuk dalam penelitian populasi karena semua siswa kelas tiga jurusan akuntansi diteliti. 


\section{HASIL DAN PEMBAHASAN}

\section{Hasil}

Analisis regresi sederhana dilakukan untuk membuktikan hipotesis penelitian, yaitu untuk mengetahui pengaruh variabel bebas, variabel terikat, dan variabel perantara. Variabel bebasnya yaitu kecerdasan emosional (X), variabel terikatnya yaitu pemahaman akuntansi (Y), dan variabel perantaranya yaitu kepercayaan diri $(\mathrm{Z})$.

Tabel 1: Ringkasan Hasil Uji Regresi

\begin{tabular}{|l|l|l|l|l|}
\hline $\begin{array}{c}\text { Hubungan } \\
\text { Antar Variabel }\end{array}$ & \multicolumn{1}{|c|}{ Persamaan Regresi } & Probabilitas & \multicolumn{1}{|c|}{ Sig } & \multicolumn{1}{c|}{ Keterangan } \\
\hline $\mathrm{YX}$ & $\overline{\mathrm{Y}}=\mathrm{a}+\mathrm{bX}=60,459+0,582 \mathrm{X}$ & 0,05 & 0,00 & H1 diterima \\
\hline $\mathrm{ZX}$ & $\mathrm{Z}=\mathrm{a}+\mathrm{bX}=4,652+0,543 \mathrm{X}$ & 0,05 & 0,00 & $\mathrm{H} 2$ diterima \\
\hline $\mathrm{YZ}$ & $\overline{\mathrm{Y}}=\mathrm{a}+\mathrm{bX}=65,886+0,657 \mathrm{Z}$ & 0,05 & 0,00 & $\mathrm{H} 3$ diterima \\
\hline
\end{tabular}

Konstanta sebesar 60,459 menyatakan bahwa jika tidak ada kenaikan nilai dari variabel kecerdasan emosional (X), maka nilai pemahaman akuntansi (Y) adalah 60,459. Koefisien regresi sebesar 0,582 menyatakan bahwa setiap penambahan (karena tanda + ) satu skor atau nilai kecerdasan emosional akan memberikan kenaikan skor senilai 0,582. Terlihat bahwa nilai probabilitas sig $=0,00$ lebih kecil dari nilai probabilitas 0,05 atau nilai 0,05 >0,00, maka $\mathrm{H}_{\mathrm{o}}$ ditolak dan $\mathrm{H}_{\mathrm{a}}$ diterima, artinya koefisien regresi signifikan. Dengan demikian bahwa terdapat pengaruh kecerdasan emosi terhadap pemahaman siswa akuntansi.

Konstanta sebesar 4,652 menyatakan bahwa jika tidak ada kenaikan nilai dari variabel kecerdasan emosional (X), maka nilai kepercayaan diri (Z) adalah 4,652. Koefisien regresi sebesar 0,543 menyatakan bahwa setiap penambahan (karena tanda + ) satu skor atau nilai kecerdasan emosional akan memberikan kenaikan skor senilai 0,543. Terlihat bahwa nilai probabilitas sig $=0,00$ lebih kecil dari nilai probabilitas 0,05 atau nilai $0,05>0,00$, maka $\mathrm{H}_{\mathrm{o}}$ ditolak dan $\mathrm{H}_{\mathrm{a}}$ diterima, artinya koefisien regresi signifikan. Dengan demikian kecerdasan emosional dan kepercayaan diri berpengaruh secara signifikan.

Konstanta sebesar 65,887 menyatakan bahwa jika tidak ada kenaikan nilai dari variabel kepercayaan diri (Z), maka nilai Pemahaman akuntansi (Y) adalah 65,886. Koefisien regresi sebesar 0,657 menyatakan bahwa setiap penambahan (karena tanda + ) satu skor atau nilai 
kepercayaan diri akan memberikan kenaikan skor senilai 0,657. Terlihat bahwa nilai probabilitas sig $=0,00$ lebih kecil dari nilai probabilitas 0,05 atau nilai $0,05>0,00$, maka $\mathrm{H}_{\mathrm{o}}$ ditolak dan $\mathrm{H}_{\mathrm{a}}$ diterima, artinya koefisien regresi signifikan. Dengan demikian pemahaman akuntansi dan kepercayaan diri berpengaruh secara signifikan.

Sedangkan untuk Pengaruh Tidak Langsung Kecerdasan Emosional (X) Terhadap Pemahaman Akuntansi (Y) Melalui Kepecayaan Diri (Z) adalah sebagai berikut

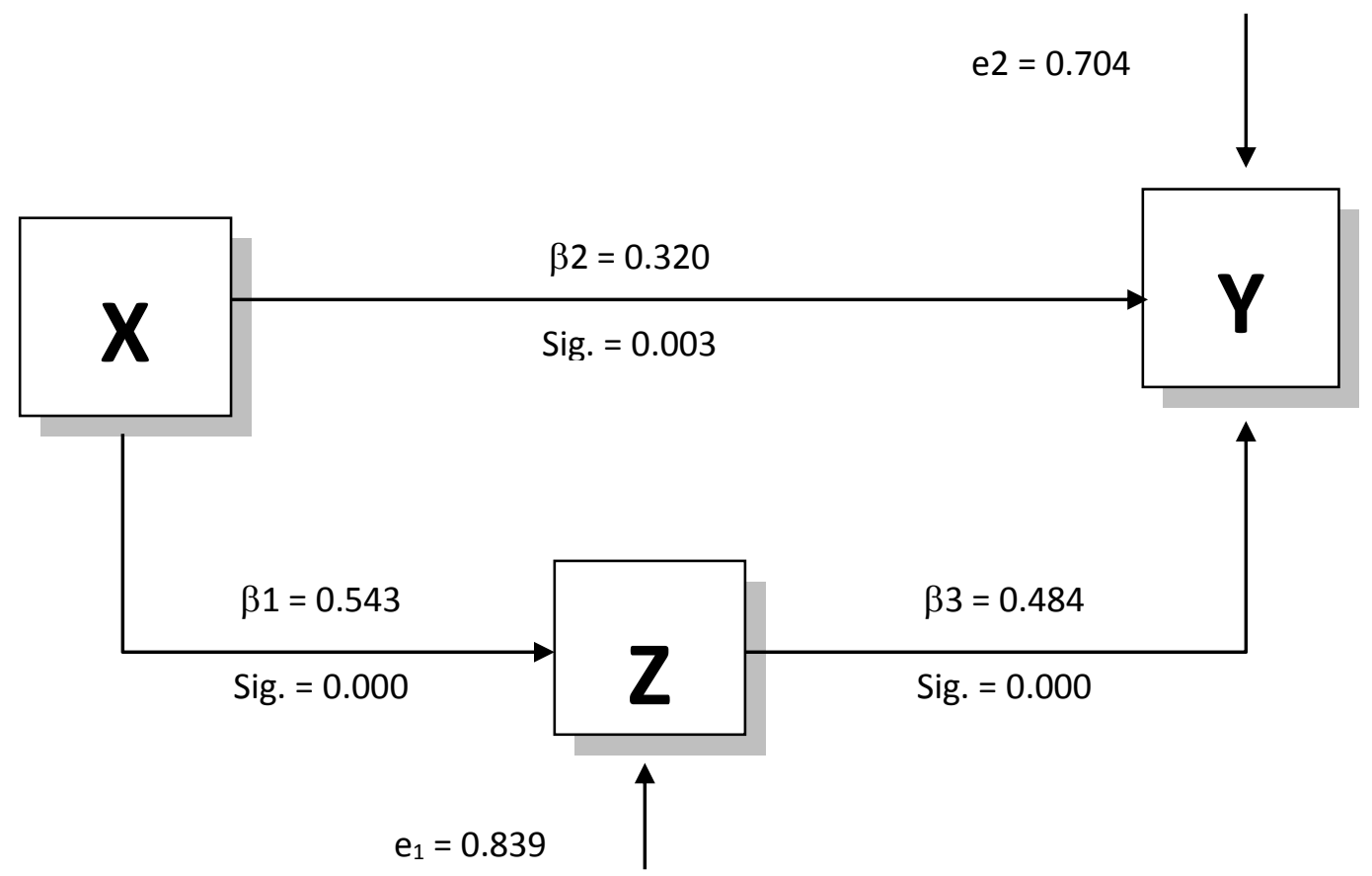

Gambar 2: Pengaruh Tidak Langsung Kecerdasan Emosional terhadap Pemahaman Akuntansi Melalui Kepercayaan Diri

Gambar diatas merupakan pengaruh tidak langsung kecerdasan emosional terhadap pemahaman akuntansi melalui kepercayaan diri. Hasil perhitungannya dapat diperoleh seperti dibawah ini.

$$
\begin{aligned}
\text { Pe1 } & =\sqrt{1-R_{1}^{2}}=\sqrt{1-0.295}=0.839 \\
\text { Pe2 } & =\sqrt{1-R_{2}^{2}}=\sqrt{1-0.504}=0.704 \\
\mathrm{Rm}^{2} & =1-\left(\mathrm{Pe}_{1}\right)^{2} \cdot\left(\mathrm{Pe}_{2}\right)^{2} \\
& =1-0,839^{2} \cdot 0,704^{2} \\
& =0.651
\end{aligned}
$$


Artinya 65,1 \% keragaman data dapat dijelaskan oleh model penelitian ini, sedangkan sisanya $34,9 \%$ dijelaskan oleh variabel lain.

$$
\begin{aligned}
\operatorname{PTL}(X-Z) & =\beta_{1} \times \beta_{3} \\
\operatorname{PTL}(X-Z) & =0,543 \times 0,657 \\
& =0,357
\end{aligned}
$$

Berdasarkan hasil analisis data diatas, pengaruh tidak langsung antara kecerdasan emosional dan pemahaman akuntansi melalui kepercayan diri sebesar 0,357 atau 35,7\%. Dari hasil perhitungan tersebut pengaruh yang ditimbulkan kepercayaan diri sebagai veriabel perantara antara kecerdasan emosional dan pemahaman akuntansi sangat kecil yaitu 35,7\%.

\section{Pembahasan}

Kecerdasan emosional dalam pembahasan ini meliputi lima komponen. Kemampuan mengenali emosi diri, kemampuan mengelola emosi diri, kemampuan memotivasi diri, kemampuan mengenali emosi orang lain, serta kemampuan membina hubungan dengan orang lain. Gambaran hasil penelitian menunjukkan bahwa banyak sekali siswa kelas XII jurusan akuntansi SMKN 1 Sumenep yang memiliki kecerdasan emosional sedang (40\%), sedikit siswa kelas XII jurusan akuntansi SMKN 1 Sumenep yang memiliki kecerdasan emosional rendah $(8,6 \%)$. Kecerdasan emosional sangat dipengaruhi oleh lingkungan, tidak bersifat menetap, dapat berubah-ubah setiap saat. Untuk itu peranan lingkungan terutama orang tua pada masa kanakkanak sangat mempengaruhi dalam pembentukan kecerdasan emosional.

Dari hasil penelitian tersebut dapat diartikan bahwa kemampuan emosional siswa kelas XII jurusan akuntansi SMKN 1 Sumenep dapat berubah. Tentunya dengan adanya kemauan siswa untuk merubahnya dan latihan secara terus menerus agar ada perubahan, serta bimbingan dari orang tua, guru, dan lingkungan yang mendukung. Hal tersebut juga berlaku pada siswa jika ingin lebih memahami pelajaran akuntansi. Tentunya dengan kerja keras dan latihan terusmenerus.

Pemahaman akuntansi merupakan hal yang menunjukkan bahwa siswa kelas XII jurusan akuntansi SMKN 1 Sumenep telah berhasil dalam mengikuti pelajaran akuntansi dalam waktu 
yang ditentukan. Dalam lingkup sekolah, pemahaman tersebut selalu diukur terus menerus dengan suatu penilaian evaluasi belajar. Penilaian terhadap siswa bukan hanya ditekankan pada aspek kognitif saja, tapi juga termasuk afektif atau sikap dan keterampilan.

Paham pada pelajaran akuntansi merupakan suatu usaha yang dilakukan dalam kegiatan belajar-mengajar dengan tujuan untuk mencapai hasil yang diinginkan. Oleh karena itu, agar siswa dapat dengan cepat memahami akuntasi, maka siswa harus rajin belajar, latihan mengerjakan soal, tidak malu bertanya apabila tidak mengerti akuntansi, serta mendapat bimbingan atau pengawasan baik dari wali kelas, guru bidang studi, serta yang paling penting yaitu pengawasan dari orang tua. Hal tersebut bertujuan agar prestasi yang telah diraih oleh siswa dapat dipertahankan dan ditingkatkan menjadi lebih baik.

Berdasarkan hasil analisis data menunjukkan bahwa kecerdasan emosional dan pemahaman akuntansi mempunyai hubungan signifikansi yang cukup besar yaitu (33,9\%). Sebenarnya faktor utama yang mendukung siswa dalam memahami akuntansi bukan hanya kecerdasan emosional saja, tapi masih banyak faktor lain yang mendukung siswa dalam memahami akuntansi. Terbukti dari hasil analisis data bahwa meskipun kecerdasan emosional siswa kelas XII jurusan akuntansi SMKN 1 Sumenep berada pada kategori sedang, namun hubungan yang ditimbulkan antara kecerdasan emosional dan pemahaman akuntansi cukup besar. Pengaruh besar tersebut disebabkan oleh tingginya nilai tes yang diperoleh siswa kelas XII jurusan akuntansi SMKN 1 Sumenep dalam pelajaran yang berhubungan dengan akuntansi. Motivasi besar yang dimiliki siswa, serta cara mengajar atau menerangkan guru yang mudah dipahami dan dimengerti oleh siswa dalam proses pembelajaran. Kecerdasan intelegensi siswa juga berpengaruh dalam memahami akuntansi, dengan demikian dapat dikatakan bahwa kecerdasan emosional bukanlah faktor utama yang mempengaruhi siswa dalam memahami akuntansi.

Menurut Stein (2002: 56), prestasi belajar yang diraih seseorang tidak semata-mata hanya ditentukan oleh kecerdasan emosional saja. Melainkan juga terdapat beberapa faktor yang mempengaruhi, diantaranya kecerdasan intelegensi, kecerdasan spiritual, lingkungan rumah, pribadi siswa, pergaulan, dan lain-lain.

Dengan kecerdasan emosional, siswa kelas XII jurusan akuntansi SMKN 1 Sumenep mampu mengetahui dan menanggapi perasaan yang dialaminya sendiri dengan baik. Serta mampu membaca dan menghadapi perasaan-perasan orang lain dengan efektif. Siswa dengan 
keterampilan emosional yang berkembang baik, kemungkinan besar akan berhasil dalam kehidupan dan memiliki motivasi untuk berprestasi.

Keberhasilan siswa dalam memahami akuntansi merupakan hal yang menunjukkan sejauh mana keberhasilan siswa dalam mengikuti proses pembelajaran dalam jangka waktu yang ditentukan. Dalam ruang lingkup sekolah, pemahaman tersebut selalu diukur terus menerus dengan suatu penilaian atau evaluasi belajar. Penilaian pada siswa bukan hanya ditekankan pada aspek kognitif saja, tapi juga termasuk pada efektif atau sikap dan keterampilannya. Pemahaman akuntansi jaga merupakan suatu usaha yang dilakukan siswa untuk mendapatkan nilai bagus dalam proses pembelajaran di sekolah.

Pernyataan diatas sesuai dengan pendapat yang diutarakan oleh Gottaman dan Goleman. Gottaman (2001) mengatakan bahwa individu yang memiliki tingkat kecerdasan emosional yang baik dapat menjadi lebih terampil dalam menenangkan dirinya dengan cepat, terampil memusatkan perhatian, baik dalam berhubungan dan cakap dalam memahami orang lain, serta kerja akademis di sekolah lebih baik sedangkan Goleman (2002) yang dikutip oleh Mischel (1960) mengenai "marsmallow challenge" di Universitas Stanford menunjukkan bahwa anak yang ketika berumur empat tahun mampu menunda dorongan hatinya, setelah lulus sekolah menengah atas, secara akademis lebih kompeten, lebih mampu menyusun gagasan secara nalar, serta memiliki gairah belajar yang lebih tinggi.

Kepercayaan diri yang akan dibahas dalam pembahasan ini adalah seberapa besarkah kepercayaan diri yang dimiliki oleh siswa kelas XII jurusan akuntansi SMKN 1 Sumenep. Berdasarkan analisis data yang diperoleh menyatakan bahwa siswa kelas XII jurusan akuntansi SMKN 1 Sumenep yang memiliki kepercayaan diri tergolong tinggi yaitu sebesar $(38,6 \%)$. Hal tersebut menunjukkan bahwa siswa kelas XII jurusan akuntansi SMKN 1 Sumenep dalam proses pembelajaran memiliki partisipasi yang sangat besar. Siswa yang memiliki kepercayaan diri besar akan lebih mudah dalam memahami pelajaran, terutama pelajaran akuntansi karena percaya diri merupakan suatu keyakinan yang dimiliki seseorang terhadap segala aspek kelebihan yang dimilikinya. Keyakinan tersebut akan membuat siswa mampu dalam mencapai berbagai tujuan dalam hidupnya.

Siswa yang memiliki kepercayaan diri yang tinggi tidak akan malu untuk bertanya dan belajar dibidang yang tidak diketahui sebelumnya. Mau belajar pada siapa saja, termasuk pada 
orang yang lebih muda sekalipun, sehingga bisa menggabungkan bidang yang sudah dikuasai dengan yang sedang dipelajarinya.

Hasil analisis data menunjukkan bahwa kecerdasan emosional dan kepercayaan diri mempunyai hubungan yang positif dan signifikan sebesar (29,5\%). Artinya, jika kecerdasan emosional siswa kelas XII jurusan akuntansi SMKN 1 Sumenep tinggi, dan kepercayaan diri yang dimiliki siswa juga tinggi, maka korelasi antara kecerdasan emosional dan kepercayaan diri juga akan semakin tinggi. Hasil analisis tersebut sesuai dengan pendapat yang disampaikan oleh Goleman (2002: 512) bahwa kecerdasan emosional mencakup kemampuan seseorang mengatur kehidupan emosinya dengan intelegensi (to manage our emotional life with intelligence); menjaga keselarasan emosi dan pengungkapannya (the oppropriateness of emotion and its expression) melalui keterampilan kesadaran diri, pengendalian diri, empati dan keterampilan sosial.

Hasil analisis data juga menunjukkan bahwa antara pemahaman akuntansi dan kepercayaan diri mempunyai pengaruh positif dan berpengaruh secara signifikan sebesar $(43,2 \%)$. Siswa yang mempunyai kepercayaan diri tinggi akan lebih mudah dalam memahami akuntansi. Artinya, jika pemahaman akuntansi yang dimiliki siswa kelas XII jurusan akuntansi SMKN 1 Sumenep tinggi dan kepercayaan diri yang dimiliki juga tinggi, maka korelasi yang ditimbulkan juga akan semakin tinggi atau besar. Pemahaman akuntansi dan percaya diri sebenarnya hampir mempunyai pengertian yang sama bila ditelaah. Paham akuntansi berarti tahu dan mengerti akan akuntansi sedangkan percaya diri berarti tahu akan kemampuan yang dimilikinya.

Siswa yang memiliki percaya diri besar akan lebih mampu mengerjakan sesuatu dan mudah mengukir prestasi. Siswa yang memiliki kepercayaan diri tinggi tidak akan malu untuk bertanya bila ada pelajaran atau hal yang tidak dimengerti. Dengan demikian siswa akan lebih cepat paham dalam proses pembelajaran, dan jika ada yang tidak dimengerti maka siswa akan bertanya untuk memahaminya terutama pada mata pelajaran akuntansi. Untuk memahami akuntansi dengan cepat siswa harus mendengarkan penjelasan guru saat mengajar, banyak berlatih mengerjakan soal-soal akuntansi, serta tidak malu bertanya untuk memahai suatu hal yang tidak dipahaminya.

Hal tersebut sesuai dengan pendapat Hakim (2002: 6) yang menyatakan bahwa secara sederhana kepercayaan diri dapat dikatakan sebagai suatu keyakinan seseorang terhadap segala 
aspek kelebihan yang dimilikinya. Keyakinan tersebut membuatnya mampu untuk bisa mencapai berbagai tujuan dalam hidupnya. Tujuan itu dapat berupa mendapatkn nilai yang bagus dalam pelajaran akuntansi serta pencapaian prestasi yang lain di lingkungan sekolah.

Dengan kecerdasan emosional, siswa mampu mengetahui dan menanggapi perasaan yang dialaminya sendiri dengan baik. Serta mampu membaca dan menghadapi perasaan-perasaan orang lain dengan efektif. Siswa dengan keterampilan emosional yang berkembang baik, kemungkinan besar akan berhasil dalam kehidupan dan memiliki motivasi untuk berprestasi.

Keberhasilan siswa dalam memahami akuntansi merupakan hal yang menunjukkan sejauh mana keberhasilan siswa dalam mengikuti proses pembelajaran dalam jangka waktu yang ditentukan. Dalam ruang lingkup sekolah, pemahaman tersebut selalu diukur terus menerus dengan suatu penilaian atau evaluasi belajar. Penilaian pada siswa bukan hanya ditekankan pada aspek kognitif saja, tapi juga termasuk pada efektif atau sikap dan keterampilannya. Pemahaman akuntansi juga merupakan suatu usaha yang dilakukan siswa untuk mendapatkan nilai bagus dalam proses pembelajaran disekolah.

Hasil analisis data juga menyatakan bahwa kecerdasan emosional dan pemahaman akuntansi mempunyai hubungan secara langsung. Selain mempunyai hubungan secara langsung, kecerdasan emosional dan pemahaman akuntansi juga mempunyai hubungan secara tidak langsung. Hubungan tidak langsung tersebut diperantarai oleh variabel kepercayaan diri, dan besarnya pengaruh yang ditimbulkan yaitu $(26,4 \%)$. Variabel kepercayaan diri disini menjadi perantara atau penghubung antara kecerdasan emosional dan pemahaman akuntansi. Siswa yang mempunyai kecerdasan emosional bagus akan lebih mudah dalam memahami akuntansi. Begitu juga dengan siswa yang memiliki kepercayaan diri tinggi akan membantu dalam proses untuk memahami akuntansi. Memahami atau belajar akuntansi dibutuhkan konsentrasi yang besar, agar nantinya tidak akan salah dalam menghitung atau mengerjakan soal yang berhubungan dengan angka-angka. Kepercayaan diri yang besar, akan lebih mempermudah siswa dalam memahami akuntansi karena dengan mempunyai kepercayaan diri yang besar siswa akan lebih mudah menyampaikan pendapatnya serta tidak akan malu untuk bertanya bila tidak mengerti akan pelajaran yang dipelajarinya atau suatu hal yang tidak dimengerti.

Kecilnya pengaruh yang ditimbulkan oleh kepercayaan diri sebagai variabel perantara disebabkan oleh adanya variabel-variabel lain yang mendukung siswa untuk memahami akuntansi. Jadi, untuk memahami akuntansi tidak hanya dipengaruhi oleh kecerdasan emosional 
dan kepercayaan diri yang mendukung siswa dalam memahami akuntansi atau mendapatkan prestasi yang bagus di bidang akademis. Melainkan ada faktor lain yang mendukung siswa kelas XII jurusan akuntansi SMKN 1 Sumenep untuk memahami akuntansi, seperti kecerdasan intelegensi, kecerdasan spiritual, lingkungan rumah, motivasi, pergaulan, dan perhatian orang tua. Pernyataan ini sama dengan pendapat yang diutarakan oleh Stein.

Menurut Stein (2002: 56) menyatakan bahwa prestasi belajar yang diraih seseorang tidak semata-mata hanya ditentukan oleh kecerdasan emosional saja. Melainkan juga terdapat beberapa faktor lain yang mempengaruhi, diantaranya kecerdasan intelegensi, kecerdasan spiritual, lingungan rumah, pribadi siswa, pergaulan dan lain-lain.

\section{SIMPULAN}

Berdasarkan hasil penelitian diperoleh kesimpulan bahwa ada pengaruh yang signifikan antara kecerdasan emosional dan pemahaman akuntansi. Pengaruh yang ditimbulkan cukup besar yaitu $(33,9 \%)$ artinya jika kecerdasan emosional siswa kelas XII jurusan akuntansi tinggi, maka pemahaman akuntansi yang dimiliki siswa kelas XII jurusan akuntansi tinggi. Pengaruh tidak langsung antara kecerdasan emosional dan pemahaman akuntansi melalui kepercayaan diri sangat kecil, yaitu (35,7\%). Artinya, semakin tinggi kecerdasan emosional dan kepercayaan diri siswa kelas XII jurusan akuntansi, maka pemahaman akuntansi yang dimiliki siswa kelas XII jurusan akuntansi akan semakin tinggi juga.

\section{DAFTAR RUJUKAN}

Admin, 2009. Arikunto, Suharsimi. 2006 . Prosedur Penelitian Suatu Pendekatan Praktek, Jakarta : Rineka Cipta.

Arikunto, Suharsimi. 2006 . Prosedur Penelitian Suatu Pendekatan Praktek, Jakarta : Rineka Cipta.

Cooper, R. K. dan Aywan S. 2002. Executive EQ : Kecerdasan Emosional dalam Kepemimpinan dan Organisasi. Jakarta: PT. Gramedia Pustaka Utama.

Goleman, D. 2002. Emotional Intellegence: Kecerdasan Emosional, Mengapa EI Lebih penting dari pada IQ. Jakarta: PT Gramedia Pustaka Utama.

Goleman, D. 2005. Emotional Intellegence: Kecerdasan Emosional, Mengapa EI Lebih penting dari pada IQ. Jakarta: PT Gramedia Pustaka Utama

Gottaman, John. (2001). Kiat-kiat Membesarkan Anak yang Memiliki Kecerdasan Emosional (terjemahan). Jakarta : PT Gramedia Pustaka Utama.

Hakim, Thursan . 2002. Mengatasi Rasa Tidak Percaya Diri. Jakarta: Arcan 
Stein, S. \& Howard E. B. 2002. Ledakan EQ 15 Dasar Kecerdasan Emosional Meraih Sukses. Terjemahan oleh Trinada Rainy \& Yudi M. 2002. Bandung: PT Kaifa. 